\title{
A Framework for Understanding of Bilingual Education in Turkey: A Mixed Method Approach
}

\author{
Burhan Ozfidan ${ }^{1}$, Lynn M. Burlbaw ${ }^{1}$ \\ ${ }^{1}$ Department of Teaching, Learning and Culture, Texas A\&M University, USA \\ Correspondence: Burhan Ozfidan, Department of Teaching, Learning and Culture, Texas A\&M University, USA.
}

Received: August 16, 2017

Accepted: September 15, 2017

Online Published: September 20, 2017

doi:10.11114/jets.v5i10.2533

URL: https://doi.org/10.11114/jets.v5i10.2533

\begin{abstract}
This study seeks to identify the obstacles and opportunities involved in setting up a bilingual education system and to identify the challenges and benefits associated with the daily experience of maintaining a bilingual education model. This study discusses the benefits of developing a bilingual education program and what these programs can offer regarding concerns related to the lives of minority people in Turkey. Explanatory sequential mixed method was used for this study. The first phase of this study was a survey that measured the perspectives of educators regarding potential bilingual education curricula in Turkey. The second phase comprised a qualitative data collection process to expand on the findings of quantitative results. For quantitative data collection, 140 participants responded the survey instrument. Participants included 96 males and 44 females. For qualitative data collection, eight participants were interviewed. Both quantitative and qualitative data reflected the benefits of a bilingual education program. First, minority students who are taught by means of a bilingual education program can protect their linguistic knowledge, cultural heritage, ethnic, and religious identity. Second, they can increase their understanding of linguistic and cultural diversity. Third, school attendance at the primary school level could be increased. Fourth, a bilingual program could contribute to the reduction of inequalities.
\end{abstract}

Keywords: bilingual education, Turkey, culture, linguistics

\section{Introduction}

Bilingual education comprises teaching academic content in two languages, usually a mainstream language (L1) and a minority language (L2) in accordance with the program model (Ozfidan, Burlbaw, \& Kuo, 2016). Experts such as Cenoz (2012), Baker (2011), Lasagabaster (2001), Cummins (2000), and Genessee and Gandara (1999) in the field of bilingual education have emphasized that bilingual education provides language skills that aid in employment, increase the educational success of students, encourage peace among different ethnic groups, support equality in educational settings, help to solve social conflicts among ethnic groups, and benefit students who have different ethnical background in the community. Therefore, to build a strong bridge between two different ethnic groups, a bilingual education program could play a prominent role (Krashen, 2000).

This study seeks to identify the obstacles and opportunities involved in setting up a bilingual education system and to identify the challenges and benefits associated with the daily experience of maintaining a bilingual education model. This study discusses the benefits of developing a bilingual education program and what these programs can offer regarding concerns related to the lives of minority people in Turkey.

\section{Literature Review}

Receiving bilingual education has many benefits, such as preserving cultural identity, ethnic identity, and the linguistic knowledge of minority group and helping to socialize people for full participation in their communities (Cummins, 2000; Ngai, 2002). Being bilingual means students can understand the content of their lessons more effectively, leading to success in their education (Bialystok, Peets, \& Moreno, 2014). When students receive education in their mother tongue, it is likely that they will be able to express their thoughts, ideas and feelings better in their classes. This, in turn, gives them the self-confidence they need to be successful in their courses (Cummins, 2001; Ricento, 2013).

For children and adults, there are numerous benefits of bilingual education. A bilingual education can consolidate the brain's executive function and change the shape and function of the brain's certain regions (Baker, 2011). Bilingual people, particularly children, are better at dealing with conflict management. Research says that speaking a second 
language may give children a more global perspective. Children who speak more than one language are more cognitively developed (Hakuta, 1990). Several researchers have written about how bilingual education conserves minority people's cultural heritage, linguistic knowledge, religious, and ethnic identity, and increases particularly minority children's educational success, promotes peace between different ethnic groups, and provides equality in education (Bialystok, 1991; Ozfidan, \& Ugurlu, 2015; Ozfidan, \& Burlbaw, 2016). This study seeks to identify the obstacles and opportunities involved in setting up a bilingual education system and to identify the challenges and benefits associated with the daily experience of maintaining a bilingual education model. This study discusses the benefits of developing a bilingual education program and what these programs can offer regarding concerns related to the lives of minority people in Turkey.

In Turkey, some minority languages such as Arabic, Laz, Kurdish, and Zaza are currently being introduced in schools; however, a lack of teachers and a lack of textbooks have inhibited this learning (Kaya, 2015). The textbooks used have been written in monolingually in Turkish, and they do not even mention anything about any of these minority groups. Therefore, none of them reflects the social diversity existing in the country (Kyriakou \& Kaya, 2011).

The education system in 2012 was reformed using something called the $4+4+4$ system that included 4 years of primary education, first level, 4 years of primary education, second level and 4 years of secondary education, and the state increased the number of elective courses. Living Languages and Dialects is one of the elective courses offered in the $5^{\text {th }}$ grade within the new curriculum. The state increased the number of elective courses for students whose mother tongue is different than that of others, but because of the lack of materials and teachers, these courses were not opened. According to the some politicians, this was a tactic to make the minority groups give up their demands of being taught in mother tongue (Kaya, 2015).

The government in Turkey began elective courses in some minority languages such as Zaza and Kurdish in 2012, Laz in 2013, Georgian in 2014 respectively. However, because of the lack of teachers and materials, the enrolment in these courses is not increasing rapidly.

\section{Methods}

An explanatory sequential mixed method was used for this study. The first phase of this study's explanatory sequential mixed method was a survey that measured the perspectives of educators regarding potential bilingual education curricula in Turkey. The mixed method approach enabled researchers to have a more in-depth information and knowledge of a problem as well as to provide rich data sets. The method assisted in increasing the reliability and validity of the findings through the triangulation of the difference results of the evidence. According to Onwuegbuzie and Leech (2006), "Because of its logical and intuitive appeal, providing a bridge between the qualitative and quantitative paradigms, an increasing number of researchers are utilizing mixed methods research to undertake their studies" (p. 482). Both quantitative and qualitative data enable researchers to expand comprehension of the problem and to enrich the generalization of the outcomes from a sample to a population (Creswell, 2007; Creswell \& Plano-Clark, 2011).

\subsection{Data Collection and Procedure}

For quantitative data collection, 140 participants responded the survey instrument. Participants included 96 males and 44 females. For qualitative data collection, eight participants were interviewed; four of whom were Turkish and the other four had ethnic backgrounds other than Turkish. In accordance with the IRB guidelines of Texas A\&M University (reference \#043138) (Appendix A), the participations were voluntary, and they could drop out at any phase of the study if they did not want to continue. The quantitative data were collected in spring 2017. A survey instrument was used to gather perceptions of adults living in Turkey concerning the implementation of a bilingual education system, which would include education in both Turkish and minority languages. The researcher met with his mentor and individuals from his previous workplace to generate suggested names of individuals who could complete an interview. All IRB guidelines set forth by Texas A\&M University were followed. The sample size was determined by emerging saturation categories and themes (Rossman \& Rallis, 2003). Saturation, according to Munhall (1994), is, "full immersion into phenomena in order to know it as comprehensively, thoroughly, and fully as possible" (p. 107). Saturation is also an in-depth investigation of the phenomenon being studied (Rossman \& Rallis, 2003). After individuals were identified to participate this study the researcher met with them in their offices or at an agreed upon meeting site and discussed the purpose in gathering this data with them. The participants were informed that their responses would not be identifiable, and the names and responses of all participants would be kept confidential. When they decided to participate in the interview, a digital recorder was turned on. The data on the digital recorder was stored in the device until the data was uploaded to a password-protected computer. 


\subsection{Reliability and Validity}

The researcher used Cronbach's alpha to analyze the questionnaire data for reliability. Because factor analysis was used, Cronbach's alpha scores were created while running the data on SPSS. Table 1 indicates that the Cronbach's alpha internal consistency measure was found to be high across all 13 items $(\alpha=.98)$. For Cronbach's alpha, a minimum value of .70 is considered acceptable (Nunnally, 1978). Hence, the survey instrument was reliable.

Table 1 . Reliability statistics

\begin{tabular}{ll}
\hline Cronbach's alpha & N of Items \\
\hline .984 & 13 \\
\hline
\end{tabular}

Likewise, academicians who are experts in the field of bilingual education in Turkey and the United States reviewed the questionnaires for content/face validity. The results for validity in the survey indicated a statistically significant correlation. The correlation $(\mathrm{rs}=.520, \mathrm{p}=.000)$ can be considered to be a moderate/medium correlation (.40 -.60). (See Laerd Statistics, n.d.) Therefore, this questionnaire was found to have content validity.

For the interview questions, an inter-rater procedure was computed to evaluate the agreement between the two coders used in this study. These two coders were Turkish and faculty members in the department of linguistics. Using SPSS, a .67 correlation value was computed for an inter-rater reliability. For the interview questions, Cohen's Kappa was used to measure reliability. The inter-rater analysis's results were Kappa $=.712$ with $\mathrm{p}<.001$. This measure of agreement was considered acceptable and statistically significant. In general, according to Landis and Koch (1977), a value of Kappa .80 is considered outstanding, values for Kappa from .60 to .79 are considered substantial, and those from .40 to .59 are considered moderate. For Kappa values, before claiming a good level of agreement most statisticians generally prefer values to be greater than .7 but values of least .6 are acceptable. Therefore, the instrument was found to be reliable.

\section{Findings}

The quantitative data was collected from the survey instrument, and the results were reported in the quantitative data findings. The data that were collected from the interview instrument, and the results were reported in the qualitative data findings.

\subsection{Results of Quantitative Data Analysis}

Table 2. Percentage of participants about benefits of bilingual education

\begin{tabular}{|c|c|c|c|c|c|c|}
\hline \# & Item & $\begin{array}{l}\text { Strongly } \\
\text { Disagree }\end{array}$ & Disagree & Neutral & Agree & $\begin{array}{l}\text { Strongly } \\
\text { Agree }\end{array}$ \\
\hline 1 & $\begin{array}{l}\text { Bilingual education can increase employment among the } \\
\text { minority groups. }\end{array}$ & $\begin{array}{l}5.71 \% \\
(8)\end{array}$ & $\begin{array}{l}7.14 \% \\
(10)\end{array}$ & $\begin{array}{l}5.00 \% \\
(7)\end{array}$ & $\begin{array}{l}57.14 \% \\
(80)\end{array}$ & $\begin{array}{l}25.00 \% \\
(35)\end{array}$ \\
\hline 2 & Bilingual education improves employment skills. & $\begin{array}{l}3.57 \% \\
(5)\end{array}$ & $\begin{array}{l}7.86 \% \\
(11)\end{array}$ & $\begin{array}{l}9.29 \% \\
(13)\end{array}$ & $\begin{array}{l}52.14 \% \\
(73)\end{array}$ & $\begin{array}{l}27.14 \% \\
(38)\end{array}$ \\
\hline 3 & $\begin{array}{l}\text { Students who complete their schooling in bilingual education can } \\
\text { more easily learn a third language. }\end{array}$ & $\begin{array}{l}3.57 \% \\
(5)\end{array}$ & $\begin{array}{l}7.86 \% \\
(11)\end{array}$ & $\begin{array}{l}11.43 \% \\
(16)\end{array}$ & $\begin{array}{l}32.14 \% \\
(45)\end{array}$ & $\begin{array}{l}45.00 \% \\
(63)\end{array}$ \\
\hline 4 & Bilingual education increases the students' educational success. & $\begin{array}{l}5.00 \% \\
(7)\end{array}$ & $\begin{array}{l}5.71 \% \\
(8)\end{array}$ & $\begin{array}{l}7.14 \% \\
(10)\end{array}$ & $\begin{array}{l}40.71 \% \\
(57)\end{array}$ & $\begin{array}{l}41.43 \% \\
(58)\end{array}$ \\
\hline 5 & $\begin{array}{l}\text { Bilingual education promotes peace among the members of a } \\
\text { society. }\end{array}$ & $\begin{array}{l}5.00 \% \\
(7)\end{array}$ & $\begin{array}{l}4.29 \% \\
(6)\end{array}$ & $\begin{array}{l}6.43 \% \\
(9)\end{array}$ & $\begin{array}{l}42.14 \% \\
(59)\end{array}$ & $\begin{array}{l}42.14 \% \\
(59)\end{array}$ \\
\hline 6 & $\begin{array}{l}\text { Bilingual education contributes to social justice such as equal } \\
\text { educational rights. }\end{array}$ & $\begin{array}{l}5.00 \% \\
(7)\end{array}$ & $\begin{array}{l}7.86 \% \\
(11)\end{array}$ & $\begin{array}{l}7.14 \% \\
(10)\end{array}$ & $\begin{array}{l}37.86 \% \\
(53)\end{array}$ & $\begin{array}{l}42.14 \% \\
(59)\end{array}$ \\
\hline 7 & Bilingual education strengthens democracy. & $\begin{array}{l}4.35 \% \\
(6)\end{array}$ & $\begin{array}{l}7.25 \% \\
(10)\end{array}$ & $\begin{array}{l}7.97 \% \\
(11)\end{array}$ & $\begin{array}{l}36.23 \% \\
(50)\end{array}$ & $\begin{array}{l}44.20 \% \\
(61)\end{array}$ \\
\hline 8 & Bilingual education promotes tolerance among students. & $\begin{array}{l}4.38 \% \\
(6)\end{array}$ & $\begin{array}{l}7.30 \% \\
(10)\end{array}$ & $\begin{array}{l}6.57 \% \\
(9)\end{array}$ & $\begin{array}{l}41.61 \% \\
(57)\end{array}$ & $\begin{array}{l}40.15 \% \\
(55)\end{array}$ \\
\hline 9 & $\begin{array}{l}\text { Bilingual education promotes equality of opportunity for } \\
\text { students. }\end{array}$ & $\begin{array}{l}4.29 \% \\
(6)\end{array}$ & $\begin{array}{l}7.14 \% \\
(10)\end{array}$ & $\begin{array}{l}7.14 \% \\
(10)\end{array}$ & $\begin{array}{l}40.00 \% \\
(56)\end{array}$ & $\begin{array}{l}41.43 \% \\
(58)\end{array}$ \\
\hline 10 & Bilingual education promotes acceptance of cultural diversity. & $\begin{array}{l}4.32 \% \\
(6)\end{array}$ & $\begin{array}{l}5.04 \% \\
(7)\end{array}$ & $\begin{array}{l}7.91 \% \\
(11)\end{array}$ & $\begin{array}{l}42.45 \% \\
(59)\end{array}$ & $\begin{array}{l}40.29 \% \\
(56)\end{array}$ \\
\hline 11 & $\begin{array}{l}\text { Bilingual education helps to resolve social conflicts among } \\
\text { ethnic groups. }\end{array}$ & $\begin{array}{l}3.57 \% \\
(5)\end{array}$ & $\begin{array}{l}8.57 \% \\
(12)\end{array}$ & $\begin{array}{l}7.86 \% \\
(11)\end{array}$ & $\begin{array}{l}36.43 \% \\
(51)\end{array}$ & $\begin{array}{l}43.57 \% \\
(61)\end{array}$ \\
\hline 12 & $\begin{array}{l}\text { Bilingual education psychologically benefits students from } \\
\text { ethnic minorities. }\end{array}$ & $\begin{array}{l}3.57 \% \\
(5)\end{array}$ & $\begin{array}{l}4.29 \% \\
(6)\end{array}$ & $\begin{array}{l}6.43 \% \\
(9)\end{array}$ & $\begin{array}{l}35.71 \% \\
(50)\end{array}$ & $\begin{array}{l}50.00 \% \\
(70)\end{array}$ \\
\hline 13 & $\begin{array}{l}\text { The Turkish government should financially support bilingual } \\
\text { education. }\end{array}$ & $\begin{array}{l}5.00 \% \\
(7)\end{array}$ & $\begin{array}{l}6.43 \% \\
(9)\end{array}$ & $\begin{array}{l}2.14 \% \\
(3)\end{array}$ & $\begin{array}{l}31.43 \% \\
(44)\end{array}$ & $\begin{array}{l}55.00 \% \\
(77)\end{array}$ \\
\hline
\end{tabular}


Note: Item 8 had 137 respondents; Item 7 with 138 respondents, Item 10 had 139 respondents. All other items had 140 respondents. " 1 = Strongly Disagree, $2=$ Disagree, $3=$ Neutral, 4 = Agree, and $5=$ Strongly Agree."

Table 2 below provides an overall summary of the descriptive findings of the potential benefits of a program of bilingual education. This table indicates that a bilingual education program in Turkey was perceived as providing language skills and improving employment skills for minority groups (Items 1 and 2). This table also indicates that respondents say that a bilingual education program would increase the educational success of students, promote peace between different ethnic societies, and provide equality in educational settings (Items 3, 4, 5, and 6). Bilingual education, according to the respondents, promotes equality of opportunity among students and acceptance of cultural diversity (Items 7, 9, and 10). It also would help to solve social conflicts between different ethnic societies and psychologically makes them feel better (Item 11 and 12). Lastly, Table 2 showed that respondents believe the Turkish government should financially support bilingual education (Item 13).

Table 3 below indicates the mean scores and standard deviation values of each item in Table 2. The highest mean score in this table was 4.25 for the statement "the Turkish government should financially support bilingual education." This emphasizes the government in Turkey should financially support bilingual education. The lowest mean score was 3.89 for the statement "bilingual education can increase employment among the minority groups." This emphasizes bilingual education adequately provides language skills to help minority groups in gaining employment. Table 3 also shows that the $6^{\text {th }}$ item, which was "bilingual education contributes to social justice such as equal educational rights" had the highest standard deviation at 1.12, which indicates that a high level of differentiation exists in this item. The $2^{\text {nd }}$ and $12^{\text {th }}$ items, which were "bilingual education improves employment skills" and "bilingual education psychologically benefits students from ethnic minorities," had the lowest standard deviations with a value of 1 . This indicates that a low level of differentiation exists. According to Bland and Altman (1996), "a high standard deviation indicates a heterogeneous group" (p. 48).

Table 3. Perception scale on the benefits of bilingual education (Mean scores and standard deviation values)

\begin{tabular}{llll}
\hline$\#$ & In your opinion, & Mean & SD \\
\hline 1 & Bilingual education can increase employment among the minority groups. & 3.89 & 1.05 \\
2 & Bilingual education improves employment skills. & 3.91 & 1.00 \\
3 & Students who complete their schooling in bilingual education can more easily learn & 4.07 & 1.09 \\
& a third language. & 4.08 & 1.08 \\
4 & Bilingual education increases the students' educational success. & 4.12 & 1.05 \\
5 & Bilingual education promotes peace among the members of a society. & 4.04 & 1.12 \\
6 & Bilingual education contributes to social justice such as equal educational rights. & 4.09 & 1.09 \\
7 & Bilingual education strengthens democracy & 4.06 & 1.08 \\
8 & Bilingual education promotes tolerance among students. & 4.07 & 1.08 \\
9 & Bilingual education promotes equality of opportunity for students. & 4.09 & 1.03 \\
10 & Bilingual education promotes acceptance of cultural diversity. & 4.08 & 1.09 \\
11 & Bilingual education helps to resolve social conflicts among ethnic groups. & 4.24 & 1.00 \\
12 & Bilingual education psychologically benefits students from ethnic minorities. & 4.25 & 1.11 \\
13 & The Turkish government should financially support bilingual education.
\end{tabular}

Notes: All items had 140 respondents, except for Item 7 with 138, Item 8 with 137 respondents, and Item 10 with 139 respondents. " 1 = Strongly Disagree, $2=$ Disagree, $3=$ Neutral, 4 = Agree, and $5=$ Strongly Agree."

\subsection{Results of Qualitative Data Analysis}

According to respondents, a bilingual education program in Turkey could provide an opportunity for students who are ethnically different than others to have equal access to education. Equal educational environment has been found to help students from minority groups to achieve academic success. For instance, Krashen (2000) asserted that bilingual education can contribute to the reduction of socio-economic inequalities and enable minority students to be more psychologically comfortable.

All interviewees who were not ethnic Turks stated that they had many difficulties during the school years because they were unable to speak with teachers in their mother tongue. Typically, language minority students who begin schooling with poor Turkish language skills usually do not pursue their education (Krashen, 2000). One of the interviewees who was ethnically different than Turkish said:

We couldn't speak Turkish, and our teacher couldn't speak our native language. This was a very big issue for us. We all who could not speak Turkish failed all our homework and exams. There were 46 students in our class. There were only 9 students who didn't know Turkish. We all failed the class at the end of our first year of elementary school. Since we failed in our first year of schooling, we didn't want to continue our education. That was affected our further education experience negatively. 
This interviewee also stated that because minority students do not have equal opportunities in the classroom they might fail in their first and/or second year of elementary school, or they might not want to continue their schooling. Most minority children in Turkey do not continue their education and drop out of school because there is not equal access to knowledge through education (Kaya, 2015).

According to both Turkish and the interviewees who had ethnically different backgrounds, bilingual education presents an opportunity for equal access to education on part of the students having a different mother tongue than most students. For example, an interviewee who was a teacher and had a different ethnical background than Turkish stated that:

I had a student; a fifth-grade special needs student. The student was considered to have high-level special needs. I realized that his major issue was language for sure. In fact, when I spoke Arabic (Arabic is my first language) with him, he communicated very well. We as teachers first solved his language issue by teaching him the Turkish language. Now he is 21 years old, and this is his second year in medical school. I think if minority students receive a fair education, perhaps they will have a better future.

He also asserted that, if the government could at least develop a local bilingual education program, this program might help most minority students who are suffering from problems caused using the Turkish language. This opinion agrees with that of Cummins (2008) who also asserted that all minority students could have equal opportunity if they were taught within a bilingual education program.

Bilingual education, according to both the Turkish and the interviewees who had ethnically different background, fosters interpersonal communication with its ability to bring individuals from diverse ethnic groups together. For example, a Turkish interviewee who was a teacher stated that:

One of fifth grade student, called M, had many challenges in the classroom since he did not have equal opportunities like other students. This student was well-spoken in Arabic. He was speaking Arabic very correctly with his friends and had very good communication with them and his teachers. But he couldn't communicate in Turkish. And he didn't understand anything in classes. Just some of teachers were trying to help him since they could speak Arabic, but it was not enough for him to be successful in his classes. I was so sad for him. He was really adorable!

The interviewee also stated that most minority group children do not want to continue their education because they do not have equal opportunities in the classrooms. This situation has created problems across Turkey because most minority people in the country are not educated, and thus they either cannot find a job or are not in an advantageous position in their job (Kaya, 2015).

Some of the interviewees who were ethnically different asserted that many minority students are not equal in the education system in Turkey, and they are afraid of teachers. An interviewee who had a different ethnical background in Turkey shared his memory about a teacher who made him scared in class. He stated that:

One day, one of the teachers called me to stand in front of the blackboard. The teacher started asking, "Did you wash? Did you wash your face and hands? Did you brush your teeth?" After he asked these questions, I answered right away saying" No, I didn't, I swear I didn't, I swear to God I didn't do anything." Since I didn't understand him I thought he was blaming me for something. Afterwards, I understood what was going on.

He also stated that such examples are very common for minority students in Turkey. They do not have equal opportunities in school or any other social environments. A bilingual education program might be a remedy for minority students who suffer from language or equality issues.

A bilingual education program in Turkey, according to some of the Turkish interviewees, might contribute to the reduction of socio-economic inequalities. For instance, a Turkish interviewee stated that:

Special measures should be implemented for students who, due to poverty and socio-economic conditions, do not have equal educational opportunities and are at risk of dropping out of school; for example, scholarships should be given to students from disadvantaged groups, a special monitoring system should be established to ensure the attendance of these students and, in cases of absenteeism, the school should take special measures to resolve the problem.

This will make students more successful in their education and help them socialize for full participation in the community. The government should support minority students who have lower income, and they should provide scholarships for them.

In addition to these, according to a non-Turkish interviewee, there is equality in education and minority students are not feeling ostracized in the society in Turkey. The interviewee stated that

I have different background then Turkish, but I didn't encounter any problem because of my ethnic background. 
When I started the elementary school, I had poor Turkish, but none of my friends or teachers treated me as if I am ethnically different than them.

The interviewee also stated that teachers at school helped him to learn Turkish language. He said teachers were going his home to practice his Turkish and to help him in different subjects such as math.

To conclude, every student should be fundamentally equal when they enter the schools or educational environments (Cummins, 2008); however, students who don't speak Turkish have an unfair disadvantage in Turkish educational system. Interviewees said that all students in Turkey are essentially equal when they enter the educational atmosphere; however, students who do not speak Turkish are at a disadvantage in the Turkish educational system.

\section{Discussion and Conclusion}

Quantitative data reflected that respondents believed that a bilingual program for minority students could provide language skills and improve employment skills for minority groups. This program, according to the respondents, could increase the educational success of minority students, bring peace into the society, and provide equality in education. Via a bilingual education program, minority students could have equal access to education. Respondents believed that, if these students were allowed to be educated in their mother tongue, the result would be helping to solve social conflicts between different ethnic groups, and these students would psychologically feel more comfortable. Therefore, according to the respondents, the government should support bilingual education programs. Children who have a good knowledge of their mother tongue have been seen to improve their literacy skills in the majority language (Baker, 2000; Skutnabb-Kangas, 2000). Developing bilingual education has been seen to improve not only the mother tongue in the school, but also student aptitudes in the language that the majorities speak (Cummins, 2000).

Qualitative data discussed how equality in education helps minority group students with respect to their academic success. Interviewees believed that, if a student feels equal in the classroom, he/she can feel psychologically more comfortable. Therefore, a bilingual education program could contribute to the reduction of inequalities. Interviewees gave examples from their life to support the fact that inequalities exist in education in Turkey. Because minority students do not have equal opportunities in the classroom, they might fail in their first and/or second year of elementary school, or they might not want to continue their schooling further. Drawing from their own experiences, respondents said that minority students had/have a tough time in schools because there weren't/aren't given equal access to learning in educational environments. Therefore, most minority people in the country are not educated, and they are having difficulty in finding a job, or they are not in an advantageous position in the jobs they currently have. A bilingual education program might be a remedy for minority students who suffer from language-based inequality. Every student should be fundamentally equal when they enter the schools or educational environments (Cummins, 2008).

Both quantitative and qualitative data reflected the benefits of a bilingual education program. First, minority students who are taught by means of a bilingual education program can protect their linguistic knowledge, cultural heritage, ethnic, and religious identity. Second, they can increase their understanding of linguistic and cultural diversity. Third, school attendance at the primary school level could be increased. Fourth, a bilingual program could contribute to the reduction of inequalities.

\section{References}

Baker, C. (2000). A parents' and teachers' guide to bilingualism ( $2^{\text {nd }}$ ed.). Clevedon, England: Multilingual Matters.

Baker, C. (2011). Foundations of bilingual education and bilingualism $\left(5^{\text {th }}\right.$ ed.).New York: Multilingual matters.

Bialystok, E. (1991). Language processing in bilingual children. Cambridge University Press. https://doi.org/10.1017/CBO9780511620652

Bialystok, E., Peets, K. F., \& Moreno, S. (2014). Producing bilinguals through immersion education: Development of metalinguistic awareness. Applied Psycholinguistics, 35(1), 177-191. https://doi.org/10.1017/S0142716412000288

Bland, J. M., \& Altman, D. G. (1996). Statistics notes: Measurement error. The BMJ, 313, 744. Retrieved from https://www.ncbi.nlm.nih.gov/pmc/articles/PMC2352111/

Cenoz, J. (2012). Bilingual educational policy in higher education in the Basque Country. Language, Culture and Curriculum, 25(1), 41-55. https://doi.org/10.1080/07908318.2011.653057

Creswell, J. W. (2007). Qualitative inquiry and research design: Choosing among five approaches $\left(2^{\text {nd }}\right.$ ed.). Thousand Oaks, CA: Sage.

Creswell, J., \& Plano-Clark, V. (2011). Designing and conducting mixed methods research. Thousand Oaks, CA: Sage.

Cummins, J. (2000). Language, power and pedagogy: Bilingual children in the crossfire. Clevedon, UK: Multilingual Matters. 
Cummins, J. (2001). Bilingual children's mother tongue: Why is it important for education. Sprog forum, 7(19), 15-20.

Cummins, J. (2008). Teaching for transfer: Challenging the two solitudes assumption in bilingual education. In J. Cummins \& N.H. Hornberger (Eds.), Encyclopedia of Language and Education 5 (2 ${ }^{\text {nd }}$ ed.) (pp. 1528-1538). New York: Springer. https://doi.org/10.1007/978-0-387-30424-3_116

Genessee, F., \& Gandara, P. (1999). Bilingual education programs: A cross-national perspective. Journal of Social Issues, 55(4), 665-685. https://doi.org/10.1111/0022-4537.00141

Hakuta, K. (1990). Language and cognition in bilingual children. Bilingual education: Issues and strategies, 47-59.

Kaya, N. (2015). Teaching in and studying minority languages in Turkey: A brief overview of current issues and minority schools. European Yearbook of Minority Issues Online, 12(1), 315-338. https://doi.org/10.1163/9789004306134_013

Krashen, S. (2000). Bilingual education: Current challenges. Educators for Urban Minorities, 1(2), 53-68.

Kyriakou, N., \& Kaya, N. (2011). Minority rights: Solutions to the Cyprus conflict. London: Minority Rights Group International.

Laerd Statistics, (n.d.). Pearson product moment correlation. Retrieved from https://statistics.laerd.com/statistical-guides/pearson-correlation-coefficient-statistical-guide.php

Landis, J. R., \& Koch, G. G. (1977). The measurement of observer agreement for categorical data. Biometrics, 33(1), 159-174. https://doi.org/10.2307/2529310

Lasagabaster, D. (2001). Bilingualism, immersion programmes and language learning in the Basque country. Journal of Multilingual and Multicultural Development, 22(5), 401-425. https://doi.org/10.1080/01434630108666443

Munhall, P. L. (1994). Revisioning phenomenology: Nursing and health science research. New York: National League for Nursing.

Ngai, P. B. (2002). Bilingual education for all: A benefits model for small towns. Bilingual Research Journal, 26(2), 269-294. https://doi.org/10.1080/15235882.2002.10668711

Nunnally, J. C. (1978). Psychometric theory ( $2^{\text {nd }}$ ed.). New York: McGraw-Hill.

Onwuegbuzie, A. J., \& Leech, N. L. (2006). Linking research questions to mixed methods data analysis procedures. The Qualitative Report, 11(3), 474-498.

Ozfidan, B., \& Burlbaw, L. M. (2016). Perceptions of Bilingual Education Model in Spain: How to Implement a Bilingual Education Model in Turkey. Journal of Ethnic and Cultural Studies, 3(1), 49-58.

Ozfidan, B., \& Ugurlu, O. (2015). The Idea of Race and Racial Differences. Electronic International Journal of Education, Arts, and Science, 1(1), 85-98.

Ozfidan, B., Burlbaw, L., \& Kuo, L. J. (2016). Perceptions of an Anticipated Bilingual Education Program in Turkey. International Education Studies, 9(10), 174. https://doi.org/10.5539/ies.v9n10p174

Ricento, T. (2013). The consequences of official bilingualism on the status and perception of non-official languages in Canada. Journal of Multilingual \& Multicultural Development, 34(5), 475-489. https://doi.org/10.1080/01434632.2013.783034

Rossman, G. B., \& Rallis, R. S. (2003). Learning in the field: An introduction to qualitative research. Thousand Oaks, CA: Sage Publications, Inc.

Skutnabb-Kangas, T. (2000). Linguistic genocide in education-or worldwide diversity and human rights? Mahwah, NJ: Lawrence Erlbaum Associates. 


\section{APPENDIX A}

\section{IRB OUTCOME LETTER}

DIVISION OF RESEARCH

DATE: September 21, 2016

\section{MEMORANDUM}

TO: Lynn M Burlbaw

TAMU - College Of Education \& Human Dev - Teaching, Learning And Culture

FROM: Dr. David Martin

SUBJECT: Expedited Approval - Reference \#043138

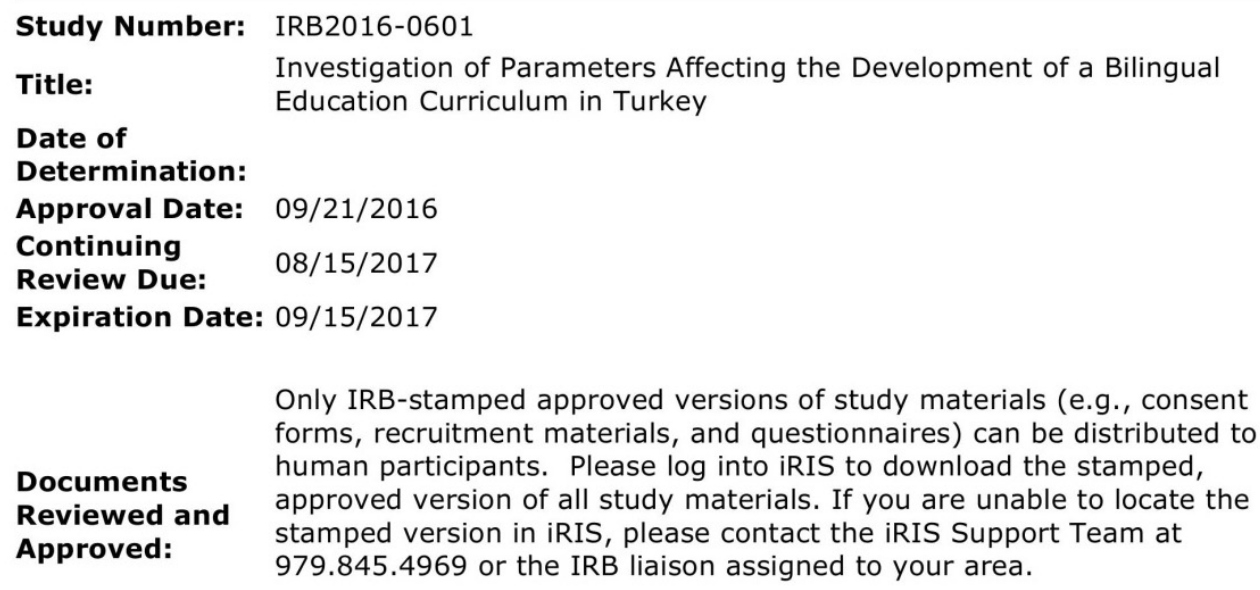

Only IRB-stamped approved versions of study materials (e.g., consent forms, recruitment materials, and questionnaires) can be distributed to

Documents Reviewed and human participants. Please log into iRIS to download the stamped, Approved: approved version of all study materials. If you are unable to locate the stamped version in iRIS, please contact the iRIS Support Team at 979.845.4969 or the IRB liaison assigned to your area.

\begin{tabular}{|c|c|c|c|}
\hline \multicolumn{4}{|c|}{ Submission Components } \\
\hline \multicolumn{4}{|c|}{ Study Document } \\
\hline Title & Version Number & Version Date & Outcome \\
\hline \begin{tabular}{|l} 
Survey \\
Questions
\end{tabular} & Version 1.1 & $08 / 17 / 2016$ & Approved \\
\hline \begin{tabular}{|l|} 
Interview \\
Questions
\end{tabular} & Version 1.1 & $08 / 17 / 2016$ & Approved \\
\hline \multicolumn{4}{|c|}{ Study Consent Form } \\
\hline Title & Version Number & Version Date & Outcome \\
\hline $\begin{array}{l}\text { consent form } \\
\text { for interview }\end{array}$ & Version 1.2 & $08 / 17 / 2016$ & Approved \\
\hline $\begin{array}{l}\text { consent form } \\
\text { for survey } \\
\text { instrument }\end{array}$ & Version 1.3 & $08 / 17 / 2016$ & Approved \\
\hline
\end{tabular}

Document of Consent: Written consent in accordance with 45 CF 46.116/ 21 CFR 50.27 Waiver approved under 45 CFR 46.117 (c) 1 or 2/ 21 CFR 56.109 (c) 1 Waiver of Consent: 
- This study has been approved for 200 participants.

- This IRB study application has been reviewed and approved by the IRB. Research may begin on the approval date stated above.

Comments: - Research is to be conducted according to the study application approved by the IRB prior to implementation.

- Any future correspondence should include the IRB study number and the study title.

Investigators assume the following responsibilities:

1. Continuing Review: The study must be renewed by the expiration date in order to continue with the research. A Continuing Review application along with required documents must be submitted by the continuing review deadline. Failure to do so may result in processing delays, study expiration, and/or loss of funding.

2. Completion Report: Upon completion of the research study (including data collection and analysis), a Completion Report must be submitted to the IRB.

3. Unanticipated Problems and Adverse Events: Unanticipated problems and adverse events must be reported to the IRB immediately.

4. Reports of Potential Non-compliance: Potential non-compliance, including deviations from protoco and violations, must be reported to the IRB office immediately.

5. Amendments: Changes to the protocol and/or study documents must be requested by submitting an Amendment to the IRB for review. The Amendment must be approved by the IRB before being implemented.

6. Consent Forms: When using a consent form or information sheet, the IRB stamped approved version must be used. Please log into iRIS to download the stamped approved version of the consenting instruments. If you are unable to locate the stamped version in iRIS, please contact the iRIS Support Team at 979.845 .4969 or the IRB liaison assigned to your area. Human participants are to receive a copy of the consent document, if appropriate.

7. Post Approval Monitoring: Expedited and full board studies may be subject to post approval monitoring. During the life of the study, please review and document study progress using the PI self-assessment found on the RCB website as a method of preparation for the potential review. Investigators are responsible for maintaining complete and accurate study records and making them available for post approval monitoring. Investigators are encouraged to request a pre-initiation site visit with the Post Approval Monitor. These visits are designed to help ensure that all necessary documents are approved and in order prior to initiating the study and to help investigators maintain compliance.

8. Recruitment: All approved recruitment materials will be stamped electronically by the HRPP staff and available for download from iRIS. These IRB-stamped approved documents from iRIS must be used for recruitment. For materials that are distributed to potential participants electronically and for which you can only feasibly use the approved text rather than the stamped document, the study's IRB Study Number, approval date, and expiration dates must be included in the following format: TAMU IRB\# 20XXXXXX Approved: $X X / X X / X X X X$ Expiration Date: $X X / X X / X X X X$.

9. FERPA and PPRA: Investigators conducting research with students must have appropriate approvals from the FERPA administrator at the institution where the research will be conducted in accordance with the Family Education Rights and Privacy Act (FERPA). The Protection of Pupil Rights Amendment (PPRA) protects the rights of parents in students ensuring that written parental consent is required for participation in surveys, analysis, or evaluation that ask questions falling into categories of protected information.

10. Food: Any use of food in the conduct of human research must follow Texas A\&M University Standard Administrative Procedure 24.01.01.M4.02.

11. Payments: Any use of payments to human research participants must follow Texas A\&M University Standard Administrative Procedure 21.01.99.M0.03

12. Records Retention: Federal Regulations require records be retained for at least 3 years. Records of a study that collects protected health information are required to be retained for at least 6 years. Some sponsors require extended records retention. Texas A\&M University rule 15.99.03.M1.03 Responsible Stewardship of Research Data requires that research records be retained on Texas A\&M property.

This electronic document provides notification of the review results by the Institutional Review Board.

\section{Copyrights}

Copyright for this article is retained by the author(s), with first publication rights granted to the journal.

This is an open-access article distributed under the terms and conditions of the Creative Commons Attribution license which permits unrestricted use, distribution, and reproduction in any medium, provided the original work is properly cited. 